\title{
NOTES UPON THE FOOD OF PREDACEOUS BEETLES.*
}

By F. M. Webster.

Pliny thought it nothing to the credit of the philosophers of his day, that while they were disputing about the number of heroes by the name of Hercules, and the site of the sepulcher of Bacchus, they should not have been able to decide whether or not the queen bee possessed a sting. ${ }^{1}$

While the problem of the bee sting has long been decided, and heroes by the name of Hercules have ceased to trouble the minds of men, there are problems of vital importance regarding the habits of the insects which, during the greater portion of the year, we meet daily in abundance, that still remain unsolved.

The most important as well as the most abundant of these insects are the beetles.

While found in almost every conceivable situation, while our naturalists count the species in their cabinets by the thousands, it would be difficult to point out a single species, the food habits of which we fully understand, when both the larva and imago state are taken under consideration.

True, we have a sort of ritual laid down by entomologists, based upon the fact that certain species have been known to feed upon certain substances, but this can no more be considered as proof that nothing else enters into their natural diet, than does the meat of which we may partake at dinner prove us to be strictly carnivorous, or the bread or fruit, that we are exclusively vegetarians.

An illustration of this double diet of beetles is found in the case of the European Silpha opaca, Linn., the larva of which has been known to feed to an injurious extent upon the leaves of the beet and mangel-wurzel. ${ }^{2}$

But one of the most fortunate in getting the benefit of our ignorance is the family Carabidx, to utter a word against which is almost considered a sacrilege.

* Although this paper does not belong with the studies made at the Laboratory, but is based entirely upon the author's personal observations, it is included with this series, with his permission, because it relates to the same subject. These observations precede, in point of time, those of the following paper.-S. A. F.

1 Pliny, Hist. Nat., 1. xi, c. 17.

2 Curtis, "Farm Insects," p. 388. 
But, true to the adage "murder will out", occasionally a species is found feeding upon vegetation with a voracity that would do credit to a Chrysomelid. Of these in Europe, besides the Zabrus gibbus in both stages, some of the Pterostichi, Amara, Omophron and Calathus latus Westw., are said to injure grain by eating off the young shoots or destroying the seed. ${ }^{3}$

Two species of Bembidium (lampos and monticola) have been destructive to the forests of upper Austria. ${ }^{4}$

Broscus cephalotes attacks the growing grain, and Aristus bucephalus devours the seeds of grass. ${ }^{5}$

In our own country the Omophron labiatum Fab. injures the shoots of young corn in the Southern States.

Harpalus caliginosus Fab. is suspected of feeding upon grain in stack in Maryland, and also of eating timothy seeds from the heads. ${ }^{6}$

E. T. Dale, of Jasper, Mo., forwarded to the editors of the American Entomologist specimens of an insect found by him feeding upon the seeds of a plant unknown to him. Upon examination they proved to be $H$. caliginosus. ${ }^{7}$

According to Mr. Mather, of Marshalltown, Iowa, the larvæ of some species of Harpalus are destructive to his evergreens, he having found them eating off the roots. ${ }^{8}$

The foregoing is a synopsis of all facts relating to the vegetable-feeding Carabidæ, so far as known to the author of this paper. A number of years ago the writer commenced the study of the food of beetles. correctly judging from what was then known, that either naturalists were in error in their suppositions or else that innocent insects were wrongly accused. And he is free to confess his partiality to the former theory as being the most correct. But after several years of study and observation, I have found to my astonishment not only the species accused but others also of this family feeding largely upon vegetable substances, both useful and noxious. Among my earliest observations on this subject I

${ }^{3}$ Report U. S. Agr. Dept., 1868, pp. 79-80.

${ }^{4}$ Deutsche Entomologische Zeitschrift, 1879 , p. 417.

5 Westwood's Introduction, I, p. 61. 、

${ }^{6}$ Report U. S. Agr. Dept., 1868, p. 80.

'Am. Ent. Vol. I, p. 80.

${ }^{8}$ Am. Ent. Vol. III, p. 26. 
noted the abundance of Carabidx about the shocks of wheat in a field where a violent wind storm had blown down a large number of sheaves, under which, upon their being replaced, large numbers of Harpalus caliginosus, pennsyivanicus and herbivagus, Pterostichus lucublandus and Anisodactylus baltimorensis were observed.

The wheat was drawn in and threshed directly from the field, and a large percentage of the kernels were badly eaten. Previous to the threshing, in another field, a specimen of $H$. pennsylvanicus was captured with a partially eaten grain of wheat in its mandibles. The eaten grains of the threshed wheat seemed to agree with the fragments found in the jaws of the beetle, and as no other destructive agencies were noted, the facts seemed to suggest that the damage was done by the before-mentioned Carabidæ. A few days after, $H$. pennsylvanicus was found eating the now fully ripe seeds from a head of upright timothy grass, and was observed to detach them from the glumes. The same species has since been seen feeding largely upon ragweed, Ambrosia artemisiafolia Linn., during September, the seeds apparently being the favorite part. A short time after it was found upon timothy grass it was observed eating the seeds of prairie grass, Panicum crus-galli L.; and the same day another individual was found devouring an Ips fasciatus Oliv., one of the Nitidulidæ, thus proving its carnivorous propensities also. $H$. caliginosus is likewise found eating the seeds of Ambrosia artemisiafolia.

$H$. herbivagus feeds largely upou the tender shoots of grass during March, cutting them off just below the surface; but later it selects the tender blades and the discolored parts usually found under boards, etc.

Amara angustata Say is found quite abundantly upon the heads of June grass, Poa pratensis L. But the most voracious Carabid enemy of this grass is the Anisodactylus sericeus Harris.

Early in June, 1878, vast numbers of these beetles were noted upon the heads of this grass; in fact, spots several yards in area were literally covered with them. After patient watching-for they are very timid-the proof 
was conclusive that the unripe seeds were what they were after and not microscopic insects as was at first supposed.

The insect is not only cunning, drawing up its legs and dropping to the ground upon the least disturbance, after the manner of a Chrysomelid, but also shows considerable ingenuity. It grasps the lower extremity of the glume tightly in its mandibles, then relaxing slightly, passes upward and again tightens its grasp-a series of movements which finally force the seed, which is now of the consistency of cream, out at the apex. This it at once proceeds to devour with an appetite which reminds one quite forcibly of a tramp who has been obliged to earn his dinner in advance. Later in the season it is found feeding in the same manner upon the seeds of Agrostis vulgaris Witt. Specimens of Anisodactylus baltimorensis Say were observed feeding upon the marrow and fatty matter clinging to the tibia of some dead animal, probably that of an ox. Attention is called to this as being in perfect accord with microscopic observations reported by Mr. Forbes in the following paper, upon another specimen found upon grass a few months later.

Calathus gregarius Say may be found abundantly upon the heads of timothy grass during the early mornings of the first of July. Of the genus Platynus only a single observation has been obtained, and this was during the latter part of June of the present year, when two specimens of $P$. cupripennis Say were seen harassing a half-grown cricket, which they had already-disabled. The carnivorous habits of beetles are often as difficult to discover as their vegetarian. Usually they are not at all in favor of public dinners, and, like beasts or birds of prey, prefer to drag their victims to some secluded nook to devour them; hence, if the observer gets any insight into this part of their domestic affairs he must take them by surprise. In this manner a Staphylinus cinnamopterus Grav. was surprised while in the act of devouring an Anomoglossus pusillus Say, having first, to guard against its escape, eaten off four of its legs.

In another instance a Dyschirius globulosus Say was observed to spring upon a small salmon-colored maggot- 
like larva, and, after disabling it, to start off to select a proper place to devour it. After the lapse of several minutes, it returned to drag its victim under a small clod of dirt and leisurely feast upon it.

After the same manner a Bradycellus rupestris Say was surprised under a stone while eating a small white thread-like worm.

Another family of beetles whose hitherto almost untarnished reputation it seems to have fallen to my lot to soil is the Coccinellidæ. With the exception of Epilachna borealis Fab. the larva of which feeds upon the vines of the gourd family, ${ }^{9}$ these insects in our country have been considered strictly carnivorous, although several European species are known to deviate from this rule.

This season, specimens of Megilla maculata DeG. have been taken while feeding upon the pollen of the dandelion, Taraxacum dens-leonis, and it is not at all improbable that the pollen of other plants also forms a part of their diet, as they are rather common upon the blossoms of plants and fruits.

No accurate estimation of the value of the Coleoptera could be obtained without including the Telephoridx. Besides Chauliognathus pennsylvanicus Forst., which has been found feeding upon the larvæ of the Conotrachelus nemuphar Hbst., ${ }^{10}$ and Telephorus bilineatus Say, which is such a powerful auxiliary in checking the ravages of the western locust, ${ }^{11}$ Podabrus tomentosus Say has been observed feeding upon the cottonwood gall-lice, Pemphigus populivenae Fitch, and the $P$. populicaulis Fitch. These beetles sometimes place themselves at the opening of the gall, occasionally as many as four together, and eatch the mature lice as they attempt an egress, and sometimes plunge their flat head and thorax into the cavity and draw forth and devour large and small indiscriminately. During the latter part of June and the first of July these beetles are very abundant, not only upon trees affected by gall-lice, but upon other plants also.

'Am. Ent., Vol. II, p. 373.

10 Am. Ent., Vol. I, pp. 35 and 51 .

${ }^{11}$ Report U. S. Ent. Comm., Vol. I, p. 302. 